\title{
Peruspalvelut Venäläistaustaisten PERHEIDEN ARJEN KANSALAISUUTTA KEHYSTÄMÄSSÄ ${ }^{1}$
}

Eveliina Heino: VTT, Helsingin yliopisto

eveliina.heino@helsinki.fi

Janus vol. 27 (4) 2019, 308-315

Olen tarkastellut väitöskirjassani venäläistaustaisten perheiden jäsenyyttä suomalaisessa yhteiskunnassa. Tutkimusaineistona käytin vuonna 2012 toteutettua 25 venäläistaustaisen perheen haastattelua sekä vuonna 2013 kerättyä yhdeksän perheen uusintahaastattelua, joita olen analysoinut laadullisten analyysimenetelmien avulla. Ilmaisulla venäläistaustainen perhe tarkoitan Jäppisen ja kumppaneiden (2007, 15) tavoin sellaista perhettä, jonka jäsenistä ainakin yksi on muuttanut Suomeen Venäjältä ja jossa on ainakin yksi samassa taloudessa asuva alle 18-vuotias lapsi. Näin ollen osassa haastatelluista perheistä toinen perheen vanhemmista on syntynyt Venäjällä ja toinen Suomessa.

Haastatteluiden aikana olen muun muassa kysynyt mitä tapahtuu, kun muuttaa toiseen maahan. Seuraavassa aineisto-otteessa yksi haastateltava vastaa tähän kysymykseen:

"Siinä tapahtuu se, et ensin sun edellinen elämä pyyhitään käytännössä pois kokonaan. Et se on ihan ensimmäinen reaktio. Sä aloitat sen elämän käytännössä nollasta. Se on ihan ensimmäinen et sun oma sisäinen elämä räjähtää ihan pieniksi kappaleiksi, et ei jää mitään. Et joudut rakentamaan kaiken alusta. Se on niin vaikeeta aloittaa se uus, sä revit ittes täysin, sä et oo kukaan enää. Ihan nollasta aloitat. Kaikki sun elämä, kaikki sun kokemus pyyhitään pois. Ei ketään kiinnosta mitä minä osasin omassa kotimaassani, ei ketään kiinnosta mitä kouluja oon käynyt kotimaassani, ei ketään kiinnosta mistä perheestä tuun. Maahanmuuttaja on just se, kuka on jättänyt oman persoonallisuuden pois. Maahanmuuttajalla ei oo persoonallisuutta mun mielestä. Koska sä joudut opiskelemaan kaiken alusta saakka. Se on niin kova prosessi, koska lapsihan sen tavallisesti tekee, mut nyt sä joudut sen tekee aikuisena”. (Tamara 2013)

Edellä esitetty haastatteluote kuvaa sitä, mitä muutoksia muutosta toiseen maahan voi seurata. Yksilöt kokevat muutokset eri vahvuisina, mutta tutkimukseen osallistuneiden haastateltavien mukaan tunnustus yhteiskunnan täysivaltaisena ja autonomisena jäsenenä, ammattilaisena ja vanhempana joutuu jossakin määrin kyseenalaiseksi muuton myötä. Jäseneksi tunnustaminen on yleensä sidottu sosiaalisiin kategorioihin, jotka ovat itsestään selviä tietyssä sosiaalisessa järjestyksessä, mutta muuttuvat sosiaalisen järjestyksen muutosten myötä kuten henkilön muuttaessa toiseen maahan (Antikainen 2010, 79; Taylor 1994, 35-47). Näin yhteiskunnan jäsenyys tulee ajankohtaiseksi vasta kun se kyseenalaistetaan ja sitä joudutaan rakentamaan uudessa ympäristössä. Lisäksi muutto toiseen maahan merkitsee usein monien aiemmin itsestään 
selvien käytänteiden ja arvojen uudelleenarviointia, sillä aiemmat tiedot ja taidot eivät välttämättä päde uudessa ympäristössä (Turtiainen 2011, 140; Siim 2007, 225).

\section{YHTEISKUNNAN JÄSENYYS ARJEN KANSALAISUUTENA}

Maahan muuttaneiden arkea ja yhteiskunnan jäsenyyttä on Suomessa usein tarkasteltu kotoutumisen sekä kulttuurin käsitteiden kautta. Tällöin huomio on kiinnittynyt ensisijaisesti siihen, mitkä tekijät auttavat tai estävät maahan muuttaneita täyttämään ennalta määritellyt kotoutumisen kriteerit tai miten oletetusta kulttuurisesta erilaisuudesta johtuvat erityiskysymykset voidaan ratkaista. Edellä mainitut lähestymistavat sisältävät kuitenkin lukuisia ongelmia. Kotoutumisen painotusta koskeva kritiikki kohdistuu ensinnäkin siihen, että on hyvin epäselvää, mikä on se kokonaisuus, johon maahan muuttaneiden oletetaan kotoutuvan. Vaarana on, että tavoitteena on utopian piirteitä saava ihanteellinen käsitys yhdenlaisesta muuttumattomasta elämäntavasta suomalaisessa yhteiskunnassa, johon ei liitetä kielteisiä piirteitä, ja jossa sivuutetaan suomalaisen kulttuurin sisäiset erot (Lehtonen 2009, 113; Lepola 2000, 329). Toiseksi kotoutumisen odotuksen esitetään sitouttavan maahan muuttaneita liikaa kansallisvaltion kontekstiin, vaikka ihmiset voivat asua useissa eri maissa elämänsä aikana integroitumatta yhteen paikkaan tai muuten elää arkeansa ylirajaisesti (esim. Haikkola 2012). Kolmanneksi myös kotouttamispolitiikka ja kotouttamistyö ovat saaneet osakseen kritiikkiä. Suomessa ja muis- sa Pohjoismaissa viranomaisten vastuu kotouttamistyöstä on keskeinen, mikä luo kotoutumiseen velvoittavan aspektin (Turtiainen 2012; Kamali 1997). Esimerkiksi yksilöllinen kotouttamissuunnitelma on sopimuksen tekniik$\mathrm{ka}$, joka sitouttaa maahan muuttaneen henkilön tiettyihin toimenpiteisiin sanktioiden ja kotouttamistuen menettämisen uhalla (Onasch \& Weide 2013, 202; Laki kotoutumisen edistämisestä 1386/2010).

Toinen Suomessa usein käytetty näkökulma, jonka avulla on lähestytty maahan muuttaneiden yhteiskunnan jäsenyyttä, on kulttuurierot. Lähestymistapa tuo esille sen, että kulttuurin käsitettä käytetään kuvatessaan vieraita ilmiöitä ja ihmisiä, joita peilataan oletetun suomalaisen kulttuurin kautta (Hiitola \& Peltola 2018; Huttunen ym. 2005). Ilmiöiden ja ihmisten "kulttuuristaminen" kohtaa kuitenkin useita haasteita. Vahvimmillaan kulttuuristamista voidaan pitää "rasismina ilman rotua" eli kulttuurirasismina siinä mielessä, että ihmisiä erotellaan kulttuuritaustan mukaan olettaen heidän jakavan tietynlaisia arvoja ja käyttäytyvän samalla tavalla (Stolcke 1995, 4). Kulttuurisia selityksiä käytetään harvoin silloin kun keskustellaan valtaväestön toiminnasta, ja siksi maahan muuttaneet näyttävät ohjautuvan kulttuurilla ja valtaväestöön kuuluvat taas tekevän rationaalisia ja yksilöllisiä päätöksiä. (Keskinen 2009; Wikkan 2002, 81.)

Kulttuuria korostavissa näkemyksissä kulttuurit esitetään selkeärajaisina, muuttumattomina sekä selkeästi toisistaan eroavina yhteisöinä. Tämä ei tuo esille elämän moninaisuutta, kulttuurin jatkuvaa muutosprosessia ja 
mahdollisuutta yksilölliseen suhteeseen kulttuuria kohtaan. (Huttunen ym. 2005; Dominelli ym. 2001.) Myös maahan muuttaneiden tukemiseen tähtäävä kulttuurin huomiointi ja näkemys siitä, että vähemmistöjen kohtaamat ongelmat johtuisivat siitä, ettei heitä ole kulttuurisesti tunnustettu, voi tahtomattaan ohjata pois yksilöllisten elämäntilateiden ja isompien epätasa-arvoa luovien rakenteiden kuten rasismin tarkastelusta. Lisäksi se antaa vähän tilaa maahan muuttaneiden itsensä määrittelylle. Puhe monikulttuurisuudesta ja monikulttuurisesta kansalaisuudesta jääkin yleensä julistukselliselle tasolle. Tarvitaan enemmän empiiristä evidenssiä tukemaan väitteitä siitä, hahmottavatko maahan muuttaneet itse yhteiskunnan jäsenyytensä kulttuurin ehdoin (Reijerse ym. 2013). Usein kulttuurisilla selityksillä ei ole myöskään paljoa tarjottavaa käytännöllisiin erityiskysymyksiin, jotka liittyvät esimerkiksi peruspalveluiden työntekijöiden ja palveluiden käyttäjien vuorovaikutukseen tai peruspalveluiden käyttöön, kuten tulkkaukseen ja selkeän palvelutiedon saamiseen (Vuori 2012, 319).

\section{Arjen kansalaisuUden osa-Alueet}

Aloittaessani väitöstutkimukseni tiesin ainoastaan sen, että haluan tarkastella venäläistaustaisten perheiden elämää Suomessa sekä peruspalveluiden käyttöä. Edellä mainitut lähestymistavat, eli kotoutuminen ja kulttuuristaminen näyttäytyivät kuitenkin itselleni ongelmallisina. Väitöstutkimuksessani lähestynkin aihetta toisin kuin on aiemmin tehty enkä ottanut lähtökohdaksi valmiita jäsenyyden kriteereitä. Olen päinvastoin kiinnittänyt huo- mioni maahan muuttaneiden omiin määritelmiin jäsenyydestään ja sen ehdoista suomalaisessa yhteiskunnassa. Käytän Listerin (1997) tavoin käsitettä arjen kansalaisuus, joka korostaa kansalaisuuden konstruktiivista ja paikallista luonnetta erotuksena virallisesta kansalaisuusstatuksesta. Nojaan Listerin ja kumppaneiden $(2007,168)$ näkemykseen siitä, että arjen kansalaisuus ilmenee neuvotteluna kansalaisuuden elementeistä: oikeuksista, velvollisuuksista, kuulumisesta ja osallisuudesta. Neuvottelulla tarkoitan sitä, että haastateltavat rakentavat arjen kansalaisuuttaan suhteessa kulttuurisiin odotuksiin, yhteiskunnallisiin diskursseihin ja institutionaalisiin käytäntöihin, muokaten ja vastustaen niitä (esim. Burr 2003). Arjen kansalaisuuden tarkastelu yhdistää rakenteellisen tason kansalaisuuden tarkastelun eli sen, miten sosiaaliset oikeudet toteutuvat peruspalveluiden kautta käytännössä, ja miten haastateltavat kokevat heihin kohdistetun kotoutumisen odotuksen. Lisäksi se sisältää ihmisten omat kokemukset sosiaalisista suhteista, arjen kohtaamisista ja kuulumisesta. Arjen kansalaisuus on kiinnostava käsite juuri sen vuoksi, että se nivoo yhteen eri tason kysymykset yksilöiden, yhteisöjen ja julkisen vallan suhteista. (Myös Vuori 2015, 395; Werbner \& Yuval-Davis 1999,4 .)

Arjen kansalaisuuden käsite on soveltuva sosiaalityön tutkimukseen, sillä sosiaalityössä tavoitellaan samoja asioita kuin kansalaisuudessa. Näitä ovat kaikkien yhteiskunnan jäsenten tasavertainen jäsenyys, yksilöiden oman toiminnan, autonomian ja sosiaalisten oikeuksien toteutumisen tukeminen (van Ewijk 2009, 174). Arjen kansalaisuuden tarkastelussa kiinnitetään huo- 
miota sosiaalityön ydinalueisiin, joita ovat julkisen vallan ja yksilön suhde sekä osallisuuden ja inkluusion kysymykset arjen kohtaamisissa (Vuori 2015; 2012; Lister 1998). Tämän vuoksi arjen kansalaisuus voi toimia työkaluna, jonka avulla tuodaan esiin sosiaalisen oikeudenmukaisuuden kysymykset ja niiden ilmentymät jokapäiväisen elämän tasolla (esim. Lister 1997, 4). Sosiaalityö ammattikäytäntönä osallistuu palveluiden käyttäjien sosiaalisten oikeuksien toteuttamiseen ja luo institutionaalisen kontekstin palveluiden käyttäjien jokapäiväiselle elämälle. Siten arjen kansalaisuuden tarkastelu lisää myös sosiaalityön itseymmärrystä.

Väitöstutkimuksessani vastaan kahteen tutkimuskysymykseen. Ensimmäisenä tutkimuskysymyksenä on: Miten haastateltavat rakentavat arjen kansalaisuuttaan? Vastatessani kysymykseen kiinnitän huomioni arjen kansalaisuuden rakentumisen prosesseihin ja sisältöihin.

Tutkimustulosten perusteella tulkitsen arjen kansalaisuuden koostuvan kolmesta osa-alueesta, joita ovat autonomia, tunnustus sekä kuuluminen. Arjen kansalainen rakentuu autonomiseksi subjektiksi, joka on vapaa tekemään valintoja omaan tahtoonsa perustuen eikä ole velvollinen ainoastaan vastaanottamaan sitä, mitä hänelle on sosiaaliturvan kautta tarjolla. Suomen kielen oppiminen sekä työllistyminen ja sosiaaliturvaetuuksista irrottautuminen ovat tärkeimmät autonomian saavuttamisen instrumentit. Tunnustuksen merkitys tulee ilmi siinä, miten haastateltavat kuvaavat omaa arjen kansalaisuuttaan yhteiskunnallisia diskursseja ja kulttuurisia odotuksia vasten sekä myötäillen että haastaen heihin kohdistettuja lei- moja ja korostaen omaa aktiivisuuttaan. Keskeistä arjen kansalaisuudessa ei ole ainoastaan valtion ja yksilön suhde, vaan myös yksilöiden keskinäiset suhteet, jotka ilmenevät valtaväestön ja maahan muuttaneiden välisissä arjen kohtaamisissa. Kuuluminen suomalaiseen yhteiskuntaan ilmenee kiinnittymisenä Suomeen ja kodin luomisena. Lisäksi se kuvaa pääsyä yhteiskunnan eri osa-alueille. Tällöin arki tuntuu ennakoitavalta ja vieraus sekä kotoutumisen vaatimukset eivät ole enää identiteettiä vahvasti määrittäviä tekijöitä. Kuulumisen korostuminen ei tarkoita sitä, että perheet olisivat sidoksissa ainoastaan yhteen paikkaan vaan sitä, että pysyvyys on lapsiperheille tärkeää.

Miesten ja naisten arjen kansalaisuus näyttäytyy erilaisena, sillä naisilla on vähemmän mahdollisuuksia saada tietoa omista oikeuksistaan sekä peruspalveluista. Osa heistä on myös taloudellisesti riippuvainen puolisostaan hoitovapaan ja heikomman kielitaitonsa vuoksi. Lisäksi peruspalveluissa erityisesti suomalais-venäläisten perheiden kohdalla asiointi tapahtuu paremmin suomea puhuvan puolison kautta, jolloin naisen näkökulma sekä ymmärryksen varmistaminen käsitellyistä aiheista jäävät taka-alalle. Erityisesti yksin muuttaneet nuoret kokevat rasismia ja yksinäisyyttä ja jäävät peruspalveluiden ulkopuolelle, mikä vaikeuttaa heidän arjen kansalaisuutensa rakentamista.

Toinen tutkimuskysymys jakaantuu kahteen osaan ja kohdistuu peruspalveluiden toimintaan arjen kansalaisuuden kontekstina. Kysyn: Millaisina peruspalvelut näyttäytyvät haastateltavien puheessa ja millaisia reunaehtoja haastateltavat esit- 
tävät peruspalveluiden luovan arjen kansalaisuuden rakentamiselle?

Peruspalvelut näyttäytyvät tutkimustulosten mukaan monitasoisina siten, että ideologisella tasolla haastateltavilla on vahva luottamus hyvinvointivaltioon sosiaaliseen turvallisuuden, resurssien uudelleenjaon ja ihmisoikeuksien takaajana. Samanaikaisesti tulee esille, että hyvinvointivaltio luo riippuvuutta peruspalveluista. Tämä voi olla myönteistä, jolloin palvelut ovat mahdollistajia, mutta myös kielteistä, jolloin riippuvuus on pitkäaikaista ja autonomiaa rajoittavaa. Institutionaalisten käytäntöjen tasolla peruspalvelut näyttäytyvät pirstaleisina ja vaikeasti saavutettavina. Epäselvä palvelutieto sekä palveluiden vaikea saavutettavuus $j a$ käytettävyys vaikeuttavat suuresti arjen kansalaisuuden rakentamista. Edellä mainitut haasteet viivästyttävät esimerkiksi vanhempien kielikursseille pääsyä ja tutkintojen pätevöittämistä sekä lasten päiväkotipaikkojen saamista ja suomen kielen oppimista ja siten autonomian saavuttamista. Vuorovaikutustaso peruspalveluiden työntekijöiden kanssa nousee merkitykselliseksi, sillä myönteisiksi koetut kokemukset tuottavat sekä käytännön tukea että tunnustusta. Kielteiset kokemukset taas vaikuttavat vahvasti siihen, miten peruspalveluihin suhtaudutaan jatkossa.

\section{LOPUKSI}

Tutkimustuloksista käy ilmi, että peruspalvelut eivät tue riittävästi haastateltavien arjen kansalaisuuden rakentamista vaikean saavutettavuuden ja käytettävyyden vuoksi. Lisäksi nykyiset kotouttamistoimet perustuvat passiiviseen kansalaisuuskäsitykseen, jossa maahan muuttaneita lähestytään kotouttamistoimenpiteiden kohteina ja heidän oletetaan integroituvan erityisesti työn kautta. Tällöin heidät nähdään Suomen työmarkkinoille muokattavana resurssina, mutta samalla jätetään huomioimatta heidän aiempaa osaamistaan.

Yksi tutkimukseni lähtökohdista oli lähestyä kriittisesti Suomessa vallalla olevia kulttuurieroja korostavaa näkökulmaa. Tutkimukseni tulokset tukevatkin tutkimuksen alussa esittämääni epäilystä kulttuuristen selitysten kaikkivoipaisuudesta, sillä tutkimuksessa tuli esille haastateltujen perheiden heterogeenisyys. Peruspalveluiden käyttöön vaikuttavat muun muassa yksilölliset sekä muuttoperusteisiin liittyvät tekijät sekä sukupuoli, palveluiden rakenteet ja perheiden kokema rasismi. Lisäksi haastateltavat tuovat esille paljon samoja peruspalveluiden käytön haasteita, joita on esitetty aiemmissa valtaväestön palveluiden käyttöä koskevissa tutkimuksissa. Näitä haasteita ovat palveluiden pirstaloituneisuus sekä palvelusta toiseen pompottelu (esim. Laitinen \& Kemppainen 2010, 149-150; Metteri 2012), byrokraattinen kohtelu (esim. Kuhmonen 1997), ammattikielen vaikea ymmärrettävyys (esim. Pohjola 2010, 42) sekä välttämättömyys nojata läheisten tukeen asioidessaan peruspalveluissa (esim. Zechner 2007, 158). Tällöin peruspalveluiden ongelmat näyttäytyvät enemmän rakenteellisilta ja kontekstisidonnaisilta kuin kulttuuritaustasta johtuvilta. Kun puhutaan kulttuurista, tulisikin tuoda esille, mitä kulttuurilla kussakin tilanteessa tarkoitetaan: onko kyse esimerkiksi lähtö- ja muuttomaan lainsäädännöllisistä ja palvelujärjestelmien eroista, sukupuolten 
ja sukupolvien välisistä suhteista vai arjen käytännöistä.

Tutkimukseni aikana olen usein kohdannut kysymyksen siitä, mitä tutkimuksessani on niin sanotusti venäläiserityistä. Haastateltavien venäläistaustaisuus nousi siinä mielessä merkitykselliseksi, että sen avulla tulivat esiin epätasa-arvoistavat rakenteet, jotka liittyvät haastateltavien kokemaan historiallisesti sidottuun rasismiin sekä siihen, että peruspalveluissa työntekijät saattoivat kohdata peruspalveluiden käyttäjiä kulttuurinsa edustajina. Myös tutkintojen pätevöittämisen vaikeus kuului näihin kysymyksiin. Maahanmuuttoerityisyys liittyi tutkimuksessani siihen, että yhteiskunnan jäsenyys tuli kyseenalaiseksi muuton myötä ja haastateltavat joutuivat rakentamaan arjen kansalaisuuttaan uudelleen.

Vaikka tunnistamani ja nimeämäni arjen kansalaisuuden eri osa-alueet ovat osittain aika lähellä perinteistä integraatiotutkimusta, arjen kansalaisuus tuo tarkemmin esille yksilöiden ja perheiden oman toimijuuden sekä tuottaa kriittisiä näkökulmia maahan muuttaneisiin kohdistuvaa normatiivista integraation odotusta kohtaan. Integraatiolle määritellyt hallinnolliset tavoitteet eivät tutkimustulosten mukaan ole ristiriidassa haastateltavien henkilökohtaisten tavoitteiden kanssa, mutta integraation normatiiviset ehdot sekä rakenteelliset kysymykset, kuten rasismi, peruspalveluiden vaikea saavutettavuus ja uudelleenkoulutuksen painotus vaikeuttavat integraatiotavoitteiden saavuttamista. Tutkimustulosten perusteella väitän Sotkasiiran $(2018,13)$ tavoin, että vallalla oleva puhe kotoutumisen tavoitteista, keinoista ja resursseista kaipaa rinnal- leen myös pohdintaa, joka lähtee maahan muuttaneiden omista näkemyksistä ja tavoitteista. Lisäksi jaan Nordbergin ja Wreden (2015) näkemyksen siitä, että maahanmuuttotutkimuksen fokus tulisi siirtää pelkästään maahan muuttaneiden ja heidän oletettujen taustakulttuureidensa tarkastelusta kansalaisuuden rakentamisen kysymyksiin, jolloin huomioidaan yhteiskunnan rakenteet, suhteet valtaväestöön sekä ne julkiset ja hallinnolliset representaatiot, jotka kehystävät maahan muuttaneiden toimintaa.

\section{ViITTEET}

${ }^{1}$ Teksti perustuu Helsingin yliopistossa 2.11.2018 pidettyyn lectio praecursoriaan.

\section{KIRJALlisUUS}

Antikainen, Maire (2010) Matkalla suomalaiseksi ja hoiva-alan ammattilaiseksi? Venäläis- ja virolaistaustaisten naisten ja suomalaisuuden kohtaamiset kuulumista rakentamassa. Helsinki: Helsingin yliopisto.

Burr, Vivien (2003) Social Constructionism. London \& New York: Routledge.

Haikkola, Lotta (2012) Monipaikkainen nuoruus - Toinen sukupolvi, transnationaalisuus ja identiteetit. Helsinki: Helsingin yliopisto.

Huttunen, Laura \& Löytty, Olli \& Rastas, Anna (2005) Suomalainen monikulttuurisuus. Paikallisia ja ylirajaisia suhteita. Teoksessa Anna Rastas, Laura Huttunen \& Olli Löytty (toim.) Suomalainen vieraskirja. Kuinka käsitellä monikulttuurisuutta. Tampere: Vastapaino, 16-40.

Jäppinen Maija \& Hurtig Johanna \& Törrönen Maritta (2007) Arjen polkuja ja kohtaamisia. Venäläistaustaiset maahanmuuttajat ja palvelujärjestelmä Kaakkois- 
Suomessa. Empathos-ehkäisevää työtä lasten ja perheiden kanssa Suomen ja Venäjän raja-alueella. Kotka: Helsingin yliopisto, Koulutus- ja kehittämiskeskus Palmenia.

Kamali, Masoud (1997) Distorted Integration. Clientization of Immigrants in Sweden. Multiethnic Papers. Uppsala: Uppsala University, Reprocentralen HSC.

Keskinen, Suvi (2009) Pelkkiä ongelmia? Maahanmuutto poliittisen keskustelun kohteena. Teoksessa Suvi Keskinen, Anna Rastas \& Salla Tuori (toim.) En ole rasisti, mutta...Mahanmuutosta, monikulttuurisuudesta ja kritiikistä. Tampere: Vastapaino \& Nuorisotutkimusverkosto, 33-46.

Kuhmonen, Kristiina (1997) Psykososiaalisten työyksikköjen palvelun laatu asiakkaan arvioimana. Tutkimus Kuopion kasvatus- ja perheneuvolasta, A-klinikalta ja mielenterveystoimistosta. Kuopion yliopistollisen opetussosiaalikeskuksen julkaisuja 3/1997. Kuopio: Kuopion yliopistollinen opetussosiaalikeskus.

Laitinen, Merja \& Kemppainen, Tarja (2010) Asiakkaan arvokas kohtaaminen. Teoksessa Merja Laitinen \& Anneli Pohjola (toim.) Asiakkuus sosiaalityössä. Helsinki: Gaudeamus, 138-180.

Laki kotoutumisen edistämisestä 1386/2010.

Lehtonen, Mikko (2009) Olen suomalainen. Teoksessa Suvi Keskinen, Anna Rastas \& Salla Tuori (toim.) En ole rasisti, mutta...Maahanmuutosta, monikulttuurisuudesta ja kritiikistä. Tampere: Vastapaino \& Nuorisotutkimusverkosto, 109-116.

Lepola, Outi (2000) Ulkomaalaisesta suomenmaalaiseksi: Monikulttuurisuus, kansalaisuus ja suomalaisuus 1990-luvun maahanmuuttopoliittisessa keskustelussa. Helsinki: Helsingin yliopisto.

Lister, Ruth \& Williams, Fiona \& Anttonen, Anneli \& Bussemaker, Jet \& Gerhard, Ute \& Heinen, Jacqueline \& Johansson, Stina \& Leira, Arnlaug \& Siim, Birte \& Tobio, Constanza \& Gavanas, Anna (toim.) (2007) Gendering citizenship in Western Europe. New Challenges for Citizenship Research in a Cross-National Context. Bristol: Policy Press.
Lister, Ruth (1998) Citizenship on the Margins: Citizenship, Social Work and Social Action. European Journal of Social Work 1 (1), 5-18.

Lister, Ruth (1997) Citizenship. Feminist Perspectives. Great Britain: Palgrave.

Metteri, Anna (2012) Hyvinvointivaltion lupaukset, kohtuuttomat tapaukset ja sosiaalityö. Tampere: Tampereen yliopisto.

Nordberg, Camilla \& Wrede, Sirpa (2015) Street-Level Engagements: Migrated Families Encountering the Local Welfare State. Nordic Journal of Migration Research, 5 (2), 67-74.

Onasch, Elizabeth \& Weide, Marjukka (2013) Teaching Integration in France and Finland: A Comparison of National Discourses within Civic Integration Programmes. Teoksessa Heidi vad Jonsson, Elizabeth Onasch, Saara Pellander \& Mats Wickström (toim.) Migrations and Welfare States: Policies, Discourses and Institutions. Helsinki: Nordic Centre of Excellence Nordwel, 174-215.

Pohjola, Anneli (2010) Asiakas sosiaalityön subjektina. Teoksessa Merja Laitinen \& Anneli Pohjola (toim.) Asiakkuus sosiaalityössä. Helsinki: Gaudeamus, 19-74.

Reijerse, Arjan \& Van Acker, Kaat \& Vanbeselaere, Norbert \& Phalet, Karen \& Duriez, Bart (2013) Beyond the EthnicCivic Dichotomy: Cultural Citizenship as a New Way of Excluding Immigrants. Political Psychology 34 (4), 611-630.

Siim, Pihla (2007) Aidit ja heidän lapsensa. Perhesuhteista neuvottelua ylirajaisissa perheissä. Teoksessa Tuomas Martikainen \& Marja Tiilikainen (toim.) Maahanmuuttajanaiset. Kotoutuminen, perhe ja työ.Väestötutkimuslaitoksen julkaisuja D 46. Helsinki:Väestöliitto, 218-244.

Sotkasiira, Tiina (2018) Kotoutumista vai hyvinvointia? Metafora-analyysi syrjäseutujen kotopalveluista. Teoksessa Johanna Hiitola, Merja Anis \& Kati Turtiainen (toim.) Maahanmuutto, palvelut ja hyvinvointi. Kohtaamisissa kehittyviä käytäntöjä. Tampere:Vastapaino, 30-52.

Stolcke, Verena (1995) Talking Culture. New Boundaries. New Rhetorics of Exclusion in Europe. Current Anthropology 36 (1), 1-13.

Taylor, Charles (1994) The Politics of Recognition. Teoksessa Amy Gutmann 
(toim.) Multiculturalism Examining the Politics of Recognition. Princeton: Princeton University Press, 25-73.

Turtiainen, Kati (2012) Possibilities of Trust and Recognition Between Refugees and Authorities. Resettlement as a Part of Durable Solutions of Forced Migration. Jyväskylä: Jyväskylän yliopisto.

Turtiainen, Kati (2011) Riippuvuus pakolaisia vastaanottavassa sosiaalityössä. Teoksessa Aini Pehkonen \& Marja Väänänen-Fomin (toim.) Sosiaalityön arvot ja etiikka. Jyväskylä: PS-kustannus, 139-162.

Werbner, Pnina \& Yuval-Davies, Nira (1999) Introduction: Women and the New Discourse of Citizenship. Teoksessa Women, Citizenship and Difference. London \& New York: Zen Books, 1-38.

Wikkan, Unni (2002) Generous Betrayal. Politics of Culture in the New Europe. Chicago: University of Chicago Press.
Vuori, Jaana (2015) Kotouttaminen arjen kansalaisuuden rakentamisena. Yhteiskuntapolitiikka 80 (4), 395-404.

Vuori, Jaana (2012) Arjen kansalaisuus, sukupuoli ja kotouttamistyö.Teoksessa Suvi Keskinen, Jaana Vuori \& Anu Hirsiaho (toim.) Monikulttuurisuuden sukupuoli. Kansalaisuus ja erot hyvinvointiyhteiskunnassa. Tampere: Tampere University Press, 235-262.

Zechner, Minna (2007) Puolisoitaan hoivaavien luottamus vanhuspalveluihin. Teoksessa Marjaana Seppänen, Antti Karisto \& Teppo Kröger (toim.) Vanhuus ja sosiaalityö. Sosiaalityö avuttomuuden ja toimijuuden välissä. Jyväskylä: PS-kustannus, 139-166. 